Final Report for University Reactor Sharing Program For the Nuclear Engineering Teaching Laboratory at The University of Texas at Austin

DOE Grant No. DE-FG03-96NE38151

Prepared by:

Sean O'Kelly

Associate Director

November 10, 1999 


\section{Reactor Sharing Program}

\section{Introduction}

The University Reactor Sharing Program provides funds for reactor experimentation to those institutions that do not normally have access to a research reactor. The Nuclear Engineering Teaching Laboratory (NETL) at the University of Texas at Austin has participated in the program since with 1997 . The NETL is the newest University Research Reactor and has only recently developed a pricing list that allowed the use of Reactor Sharing Funds. The funding was rapidly expended for significant research projects and there was little left for new opportunities or outreach programs.

Nuclear Engineering Teaching Laboratory

1 MW TRIGA

512-232-5373

FAX 512-471-4589

Summary of Projects Supported

\begin{tabular}{|l|l|l|l|l|}
\hline \multicolumn{1}{|c|}{ Institution } & \multicolumn{1}{|c|}{$\begin{array}{c}\text { Principle } \\
\text { Investigator }\end{array}$} & $\begin{array}{c}\text { Project } \\
\text { Description }\end{array}$ & $\begin{array}{c}\text { Number of } \\
\text { Graduate } \\
\text { Students }\end{array}$ & $\begin{array}{c}\text { Amount } \\
\text { Funded }\end{array}$ \\
\hline $\begin{array}{l}\text { University of } \\
\text { SW Louisiana }\end{array}$ & $\begin{array}{l}\text { Dr. Andy } \\
\text { Hollerman }\end{array}$ & $\begin{array}{l}\text { NAA Trace } \\
\text { Analysis of } \\
\text { Heavy Metals } \\
\text { in Trees }\end{array}$ & 1 & $\$ 1,260.00$ \\
\hline $\begin{array}{l}\text { University of } \\
\text { Illinois }\end{array}$ & $\begin{array}{l}\text { Dr. Robert } \\
\text { Jones }\end{array}$ & $\begin{array}{l}\text { NAA for Iodine } \\
\text { in Soils }\end{array}$ & 1 & $\$ 4,800.00$ \\
\hline $\begin{array}{l}\text { Universon } \\
\text { (Potsdam, NY) }\end{array}$ & $\begin{array}{l}\text { Dr. Philip } \\
\text { Hopke }\end{array}$ & $\begin{array}{l}\text { NAA of Wall } \\
\text { Deposition of } \\
\text { Contamination } \\
\text { in Home } \\
\text { Environment }\end{array}$ & 1 & $\$ 2,500.00$ \\
\hline $\begin{array}{l}\text { University of } \\
\text { New } \\
\text { Hampshire }\end{array}$ & Dr. J. Spear & $\begin{array}{l}\text { Trace Analysis } \\
\text { of Mine } \\
\text { Tailings and } \\
\text { Soils }\end{array}$ & 2 & $\$ 1440.00$ \\
\hline
\end{tabular}

Total Expended for the Total Project

$\$ 10,000.00$

The Reactor Sharing Program has been a great benefit and has provided funding for Nuclear Research that is not obtainable in the current funding environment. 


\section{DISCLAIMER}

This report was prepared as an account of work sponsored by an agency of the United States Government. Neither the United States Government nor any agency thereof, nor any of their employees, make any warranty, express or implied, or assumes any legal liability or responsibility for the accuracy, completeness, or usefulness of any information, apparatus, product, or process disclosed, or represents that its use would not infringe privately owned rights. Reference herein to any specific commercial product, process, or service by trade name, trademark, manufacturer, or otherwise does not necessarily constitute or imply its endorsement, recommendation, or favoring by the United States Government or any agency thereof. The views and opinions of authors expressed herein do not necessarily state or reflect those of the United States Government or any agency thereof. 


\section{DISCLAIMER}

Portions of this document may be illegible in electronic image products. Images are produced from the best available original document. 